Of Moore's relatively few 'outside' interests one recalls his abiding affection for cricket although his migration from Hove to Beaconsfield a few years ago gave him less opportunity for watching County matches.

The foregoing is mainly a catalogue of achievements but the real impact of Bill Moore was as a warm-hearted human being. His colleagues, whether senior or lowly, were his friends. He did not mince his words when he considered that the occasion demanded plain spcaking but, having said his piece, that was the end of the matter. The next time the individual on the 'receiving end' met W. R. M. he could be sure of a cheery smile that was sincere.

Bill Moore was essentially a family man. During the last war he and his wife suffered a grievous blow by the loss of one of their sons on an operational flight with R.A.F. Bomber Command.

His wife survives him together with their three other sons and one daughter.

N. C. BERRY

\title{
HENRI AUTERBE
}

ThE Institut des Actuaires Français, by the death of Henri Auterbe, has lost its distinguished Président d'Honneur. Auterbe, who died on 7 August 1968, reached the advanced age of 88. He was well known by many British actuaries, having been elected a Corresponding Member of the Institute in 1938, and became an Honorary Overseas Member when this class of membership was recently introduced.

In his tribute to Auterbe, the President of the French Institut records a varied and interesting career. Auterbe became a chemical engineer on completing his formal education, and began with a post in a sugar refinery and then in the gas industry. It was only in 1907, when he was already 27 years old, that he embarked on an actuarial carcer. He entered the Ministère du Travail by competitive examination and was appointed to the office formed in that year to control private insurance. In 1908 he gained the Diploma of the French Institut, and in 1913 became Membre Agrégé (Fellow).

From 1913 onwards he served in l'Union-Vie, one of the important Life companies in France, and became its General Manager in 1939. On the nationalization of the large Life companies in 1947, he became President-General Manager and retired two years later. However, his professional advice continued to be sought and he took an active interest in actuarial matters for many more years.

At the time of the Eleventh International Congress of Actuaries, a memorable Congress held in Paris in 1937, Auterbe was Secretary General of the Institut and it was natural that he should be elected as one of our Corresponding Members in the following year. He became President in 1942. His enthusiasm for international contacts was sustained, and he made further friends among our members when he attended the Centenary celebrations in 1948 and spoke at the Banquet. The fiftieth anniversary of the French Institut was celebrated in 1949 (the actual anniversary having occurred during the war) and a strong delegation was sent by the Institute, led by Sir George Maddex as President. A translation of Auterbe's account of the origins and progress of actuarial science in France, which formed part of his address of welcome, appears in J.I.A. 57, 76.

The resumption of International Congresses in 1951, after a break of no less than 14 years due to the war, brought Auterbe a new generation of actuarial friends. He was a member of the Council of the Permanent Committee for International Actuarial Congresses (now the International Actuarial Association) until 1961. At the informal gatherings which followed the meetings of the Council another facet of Auterbe's versatile accomplishments was revealed. In his early days he had perfected his rendering 
of patter songs in the Chansonnier tradition. Even though the British members found difficulty in following his fluent comical outpourings, rendered at Gilbertian speed, there was no mistaking their entertainment value.

It was fitting that Auterbe should have survived to celebrate the 75th Anniversary of his Institut with an international gathering in 1966 to which delegations from many countries were invited. By then his heath was failing, but not his spirit. He hardly spoke any English, which renders all the more remarkable his place in the affections of actuaries all over the world.

J. HAMILTON-JONES 